Life Science 10 (2) (2021)

Life Science

http://journal.unnes.ac.id/sju/index.php/LifeSci

\title{
Efek Rebusan Sereh (Cymbopogon citratus) Terhadap Respon Stress Oksidatif Pada Tikus Wistar Jantan (Rattus norvegicus) Diabetes
}

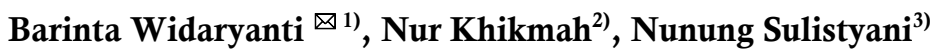 \\ 1),23)Program Studi Teknologi Laboratorium, Akademi Analis Kesehatan Manggala, Yogyakarta
}

\section{Info Artikel}

Diterima: 1 September

2021

Disetujui: 30 September

2021

Dipublikasikan: 30

November 2021

Keywords:

Cymbopogon citratus,

Diabetes mellitus, oxidative

stress,

Diabetes mellitus, sereh, stress

oksidatif

\section{Abstract}

Diabetes mellitus is a metabolic disorder with hyperglycemia. The amount of diabetic patients in Indonesia will increase rapidly without suitable treatment. High level of blood glucose will trigger oxidative stress. The objective of this research wa to investigate the effect of lemongrass on oxidative stress response that was indicated by serum and hepatic Total antioxidant capacity and Malondialdehyde level. Thirty male wistar rat were divided into five groups. $K 1$ was a normal group, K2 was a normal group with lemongrass treatment, K3 was a diabetic group induced by a single dose of Streptozotocin at a concentration of $60 \mathrm{mg} / \mathrm{kg}$ body weight, K4 was a diabetic group that was treated with glibenclamid at a concentration of $0.09 \mathrm{mg} / 200 \mathrm{gr}$ body weight, while K5 was a diabetic group treated with lemongrass at a concentration of $3.6 \mathrm{ml} / 200 \mathrm{gr}$ body weight. The result showed that lemongrass was able to reduce blood glucose levels, serum MDA and hepatic MDA levels and increased the level of total antioxidant status.

\begin{abstract}
Abstrak
Diabetes adlah kelainan metabolisme yang ditandai dengan hiperglikemia. Jumlah penderita diabetes mellitus di Indonesia akan mengalami peningkatan jika tidak ada penanganan yang sesuai. Tinggi kadar glukosa darah dapat memicu terjadinya stress oksidatif. Tujuan penelitian ini adalah untuk mengetahui pengaruh pemberian sereh terhadap respon stress oksidatif yang ditunjukan dengan kapasitas antioksidan total dan kadar malondialdehid. Tigapuluh ekor tikus wistar jantan dibagi menjadi lima kelompok. K1 adalah kelompok normal, K2 adalah kelompok normal dengan perlakuan sereh, K3 adalah kelompok diabetes yang diinduksi dengan streptozotocin $60 \mathrm{mg} / \mathrm{kg}$ berat badan single dose, $\mathrm{K} 4$ adalah kelompok diabetes yang diberi perlakuan dengan glibenklamid dengan dosis $0.09 \mathrm{mg} / 200$ gr berat badan. Sedangkan K5 adalah kelompok diabetes yang dieri perlakuan dengan rebusan sereh dengan dosis $3.6 \mathrm{ml} / 200$ gr berat badan. Hasil penelitian menunjukan bahwa rebusan sereh mampu menurunkan kadar glukosa darah, konsetrasi malondialdehid serum dan hepar, serta meningkatkan total antioksidan status pada serum dan hepar.
\end{abstract}




\section{PENDAHULUAN}

Diabetes mellitus (DM) merupakan gangguan metabolisme menahun yang diakibatkan oleh ketidakmampuan pankreas memproduksi insulin atau tubuh tidak dapat mengggunakan insulin. Penyakit ini ditandai dengan meningkatnya kadar glukosa. Pada tahun 2017 diperkirakan terdapat 451 juta orang yang menderita penyakit diabetes mellitus dengan usia 18-99 tahun, prevalensi pada usia tersebut sebesar 8.4\% dan diprediksikan akan mengalami peningkatan sebesar 9.9\% pada tahun 2045 . Peningkatan kasus DM berpengaruh terhadap kehidupan masyarakat terutana yang berpenghasilan rendah, oleh karena itu diperlukan penanganan untuk menekan prevalensi DM (Cho et al., 2018). Hiperglikemia kronis yang terjadi pada penderita DM dapat menyebabkan komplikasi diabetes mellitus seperti nefropathy, retinopathy dan neuropathy (Tarigan, et al., 2015). Beberapa studi menyebutkan bahwa komplikasi diabetes mellitus disebabkan oleh terjadinya stress oksidatif (Pieme et al., 2017, Zatalia \& Sanusi, 2013)

Stress oksidatif adalah keadaan ketidakseimbangan antara radikal bebas dan antioksidan. Produksi radikal bebas pada diabetes mellitus yang terjadi akibat autooksidasi glukosa melebihi kemampuan kemampuan antioksidan intrasel untuk menetralkannya sehingga menyebabkan kerusakan sel. Untuk menekan peningkatan produksi radikal bebas tersebut diperlukan antioksidan (Setiawan \& Suhartono, 2005). Senyawa antioksidan baik sintetik maupun alami mampu mengontrol kadar glukosa darah dan mencegah komplikasi diabetes lebih lanjut (Erlidawati, et al., 2018). Senyawa bioaktif dari beberapa tanaman telah dilaporkan memiliki sifat antioksidan, diantaranya adalah cinnamic acid, coumarine, diterpene, flavonoid, polypropanoid, tannin dan triterpene. Senyawa bioaktif tersebut hampir terdapat diseluruh bagian tanaman. Senyawa golongan polifenol yang terrdapat dalam teh juga dilaporkan memiliki efek antioksidan dan menekan stress oksidatif pada diabetes (Waltner-Law et al., 2002, Haidari, et al., 2013).

Senyawa bioaktif yang terdapat dalam minyak atsiri yang dihasilkan dari daun dan batang sereh adalah geranial, neral, limonene, geraniol dan $\beta$-myrcene. Uji DDPH pada minyak atsiri tanaman sereh tersebut menunjukan aktivitas antioksidan sebesar $89 \%$, serta dapat menurunkan kadar glukosa melalui uji hambatan $\beta$-glukooksidase (Mirghani, et al., 2012). Senyawa fenolik yang terdapat pada Cymbopogon cittratus, Cymbopogon martini dan Cymbopoggon winterianus yang terdapat di Iindonesia juga telah diketahui memiliki efek antioksidan yang ditentukan dengan DPPH dan FRAP test (Kusmardiyani, et al., 2016). Penelitian yang dilakukan oleh Garba, et al., (2020) menunjukan bahwa senyawa teh sereh yang mengandung flavonoid dan senyawa fenol memiliki efek antidiabetes, meningkatkan kemampuan toleransi glukosa, fungsi sel beta dan dislipidemia pada tikus putih diabetes yang diinduksi fruktosa. Aktivitas antioksidan dari tanaman sereh telah banyak dilaporkan, penelitian yang telah dilakukan sebelumnya juga telah menunjukan potensi hipoglikemik dan hipolipidemik rebusan sereh pada tikus wistar diabetes yang diinduksi aloksan (Widaryanti \& Tripramatasari, 2021). Penelitian ini dilakukan untuk mengetahui pengaruh pemberian rebusa batang sereh terhadap tikus wistar jantan diabetes yang 
diinduksi aloksan. Penelitian ini diharapkan dapat memberikan kontribusi ilmiah dalam pengembangan agen terapi herbal untuk menekan stress oksidatif pada kasus diabetes.

\section{METODE}

Subyek penelitian ini adalah tikus wistar jantan dengan usia 8 minggu, berat badan 150-200 g dan dalam keadaan sehat. Bahan penelitian yang digunakan adalah rebusan sereh yang dibuat dengan cara: $100 \mathrm{~g}$ batang sereh yang telah dicuci ditambah $100 \mathrm{ml}$ air, dan dipanaskan dengan api kecil hingga mendidih selama 15 menit. Penelitian ini telah memperoleh persetujuan dari Komisi Etik Penelitian Kesehatan dengan surat No. LB.01.01/KE-01/XXXV/2017.

\section{Perhitungan dosis pemberian rebusan sereh dan glibenklamid}

Penentuan pemberian rebusan sereh pada tikus wistar jantan dihitung berdasarkan faktor konversi Laurence dan Bacharah sebesar 0.018 (Martina, et al., 2019). Konsumsi rebusan sereh untuk manusia adalah $200 \mathrm{ml} /$ hari. Perhitungan dosis rebusan sereh adalah $0.018 \times 200 \mathrm{ml}=3.6 \mathrm{ml} / 200 \mathrm{gr}$ berat badan. Sedangkan dosis glibenklamid untuk manusia adalah $5 \mathrm{mg} /$ hari, maka dosis glibenklamid adalah $0.018 \times 5=0.09 \mathrm{mg} / 200$ gr berat badan .

\section{Perlakuan hewan coba}

Tikus wistar jantan sebanyak 30 ekor diadaptasikan dalam kandang selama 7 hari, kemudian dibagi menjadi lima kelompok secara acak. Kelompok K1 adalah kelompok normal yang hanya diberi pakan dan minum standar ad libitum selama 5 minggu. K2 adalah kelompok normal yang diberi rebusan sereh $3.6 \mathrm{ml} / 200$ gr BB per hari. Kelompok K3 adalah kelompok diabetes yang diinduksi dengan STZ dengan dosis $60 \mathrm{mg} / \mathrm{kg}$ BB single dose secara intraperitoneal. Kelompok K4 adalah kelompok diabetes yang diberi perlakuan dengan glibenklamid sebanyak $0.09 \mathrm{ml} / 200$ gr $\mathrm{BB}$, sedangkan $\mathrm{K} 5$ adalah kelompok diabetes dengan pemberian rebusan sereh sebanyak $3.6 \mathrm{ml} / 200 \mathrm{~g}$ BB.

Pada hari keempat setelah induksi dengan STZ, dilakukan pemeriksaan kadar glukosa darah pada semua kelompok untuk mengetahui pengaruh induksi STZ. Tikus wistar dikatakan diabetes jika kadar glukosa puasa lebih dari $250 \mathrm{mg} / \mathrm{dl}$. Setelah pemeriksaan kadar glukosa puasa kelompok K1 dilanjutkan dengan pakan dan minum standar, K2 diberi minuman rebusan sereh sesuai dosis perhitungan. K3 diberi pakan dan minum standar, K4 dilanjutkan dengan pemberian glibenklamid dengan dosis sesuai perhitungan selama 2 minggu. Pemberian rebusan sereh dan glibenklamid dilakukan secara oral dengan sonde. Selama intervensi tikus wistar dimonitor dan ditimbang berat badannya. Pada hari ke15 semua tikus wistar dipuasakan dan dikorbankan menggunakan anestesi ketamine dengan dosis $100 \mathrm{mg} / \mathrm{BB}$. Hepar diambil dan dicuci dalam buffer salin (0.9\%), kemudian dimasukan dalam larutan potassium klorida dingin (1.15\%) yang mengandung $0.1 \mathrm{mM}$ EDTA. Hepar kemudian dihancurkan dalam buffer fosfat dan dihomogenkan. Selanjutnya disentrifus pada kecepatan $3000 \mathrm{~g}$ selama 10 menit. Supernatant kembali disentrifus dengan kecepatan 15.000 g pada suhu $4^{0} \mathrm{C}$. Supernatan digunakan untuk uji biokimia. 


\section{Uji biokimia}

Kadar glukosa puasa ditentukan dengan metode enzymatic colorimetric GOD-PAP menggunakan Glucose FS ex dyasis. Sampel yang digunakan untuk pemeriksaan adalah serum, yang disiapkan dengan cara mengambil darah secara retroorbital kemudian darah disentrifus dengan kecepatan 3000 rpm selama 15 menit. Konsentrasi malondialdehid dalam serum dan hepar ditentukan sebagai biomarker terjadinya peroksidasi lipid. Uji yang digunakan adalah Lipid Peroxidation (MDA) Assay kit colorimetric (Sigma-Aldrich) dengan prosedur pemeriksaan mengikuti instruction manual kit tersebut. Total antioxidant capacity dalam serum dan hepar ditentukan dengan Total Antioxidant Status (TAS) Assay kit (Randox Laboratories) dengan prosedur sesuai dengan instruction manual kit.

\section{Analisa data}

Data pengukuran Kadar glukosa darah sebelum, sesudah induksi dan setelah pemberian rebusan sereh dianalisa dengan paired sample t test. Sedangkan hasil pengukuran konsentrasi MDA dan TAS dianalisa menggunakan ANOVA satu arah serta dianalisis multivariate menggunakan Tukey HSD pada program SPSS ver 25 for windows.

\section{HASIL DAN PEMBAHASAN}

\section{Pengaruh induksi streptozotocin (STZ) terhadap kadar glukosa darah tikus wistar jantan}

Sebanyak tiga kelompok (K3, K4 dan K5) dari lima kelompok tikus wistar jantan diinduksi dengan STZ untuk menyebabkan terjadinya hiperglikemi pada kelompok kontrol diabetes. Hasil induksi STZ dengan konsentrasi $60 \mathrm{mg} / \mathrm{kg}$ BB dosis tunggal secara intraperitoneal, menunjukkan bahwa pada tiga kelompok diabetes tersebut terjadi peningkatan kadar glukosa secara signifikan. Hasil uji paired sample $t$ test menunjukan nilai signifikansi $=0.00$. Rata-rata kadar glukosa darah pada kelompok diabetes adalah $261 \mathrm{mg} / \mathrm{dl}$ (Tabel 1).

Tabel 1. Pengaruh induksi STZ $60 \mathrm{mg} / \mathrm{kg}$ BB single dose pada tikus wistar jantan

\begin{tabular}{lcc}
\hline \multirow{2}{*}{ Kelompok perlakuan } & \multicolumn{2}{c}{ Kadar Glukosa rata-rata (mg/d1) } \\
\cline { 2 - 3 } & Sebelum induksi STZ & Setelah induksi STZ \\
\hline K1 : Normal & 81.20 & 81.97 \\
K2 : Normal + rebusan sereh & 78.92 & 79.91 \\
K3 : Diabetes & 78.77 & 261.19 \\
K4 : Diabetes + glibenklamid & 77.64 & 261.44 \\
K5 : Diabetes + rebusan sereh & 78.70 & 262.44 \\
\hline
\end{tabular}

Keterangan: K1 dan K2 tidak diiunduksi dengan STZ

Kenaikan kadar glukosa darah pada tiga kelompok diabetes menunjukan bahwa induksi STZ dengan $60 \mathrm{mg} / \mathrm{kg}$ BB secara intravena mampu merusak sel, tiga hari setelah induksi STZ dapat menyebabkan pembengkakan pada sel pankreas dan menyebabkan kerusakan pada sel $\beta$ Langerhans (Akbarzadeh et al., 2007). STZ merusak sel $\beta$ langerhan melalui transporter GLUT 2, gugus nitrosurea 
pada STZ mengalami alkilasi sehingga menyebabkan kerusakan $\beta$ pankreas, selain itu STZ merupakan donor nitric oxide yang dapat memicu peningkatan oksigen reaktif, sehingga dapat menghambat siklus krebs yang mengakibatkan terbatasnya produksi ATP pada mitokondria. Induksi STZ dengan dosis diatas $40 \mathrm{mg} / \mathrm{kg} \mathrm{BB}$ single dose secara intra peritoneal dapat menghasilkan model hewan coba diabetes tipe 2 (Nugroho, 2006, Szkudelski, 2001).

\section{Pengaruh pemberian rebusan sereh terhadap kadar glukosa}

Efek pemberian rebusan sereh terhadap kadar glukosa pada tikus wistar setelah diinduksi STZ dilakukan dengan membandingkan kelompok normal (K1 dan K2) dengan kelompok diabetes (K3, K4 dan K5). Hasil pengukuran kadar glukosa menunjukan bahwa pada kelompok kontrol normal tidak terdapat perubahan kadar glukosa selama penelitian berlangsung Hal tersebut menunjukan bahwa kondisi hewan coba dalam keadaan sehat, sedangkan pada kelompok diabetes tanpa perlakuan dengan glibenklamid dan rebusan sereh menunjukan bahwa tikus wistar tetap dalam kondisi hiperglikemia selama penelitian berlangsung. Pemberian rebusan sereh pada tikus wistar diabetes dapat menurunkan kadar glukosa sebesar $44 \%$ secara signifikan $(p=0.00)$ (Tabel 2.)

Tabel 2. Pengaruh rebusan sereh terhadap kadar glukosa darah pada tikus Wistar diabetes

\begin{tabular}{lccc}
\hline \multirow{2}{*}{ Kelompok perlakuan } & \multicolumn{2}{c}{ Kadar Glukosa rata-rata (mg/d1) } & \multirow{2}{*}{ Penurunan (\%) } \\
\cline { 2 - 3 } & Setelah induksi STZ & Setelah perlakuan & \\
\hline K1 : Normal & 81.97 & 82.66 & 0.83 \\
K2 : Normal + rebusan sereh & 79.91 & 76.32 & 4.5 \\
K3 : Diabetes & 261.19 & 265.02 & 1.4 \\
K4 : Diabetes + glibenklamid & 261.44 & 130.14 & 50 \\
K5 : Diabetes +rebusan sereh & 262.44 & 146.68 & 44 \\
\hline
\end{tabular}

Hasil penelitian tersebut sejalan dengan penelitian sebelumnya yang menunjukan bahwa rebusan sereh dengan konsentrasi 3.6 ml/200 gr BB yang diberikan selama empat mingggu dapat menurunkan kadar glukosa darah dan memperbaiki profil lipid pada tikus diabetes yang diinduksi alokan (Widaryanti \& Tripramatasari, 2021). Adeneye dan Agbaje (2007) juga menemukan bahwa ekstrak air daun sereh dengan konsentrasi $500 \mathrm{mg} / \mathrm{kg}$ BB dapat menurunkan kadar glukosa darah pada tikus wistar jantan. Efek hipoglikemik dan hipolipidemik pada tanaman sereh diduga berkaitan dengan senyawa bioaktif yang terdapat pada tamanan sereh. Kandungan senyawa yang terdapat dalam tanaman sereh antara lain adalah alkaloid, saponin dan flavonoid (Ekpenyong, et al., 2014). Alkaloid telah dilaporkan memiliki kemampuan untuk menstimulasi Growth hormone releasing hormone (GHRH), kadar GH tinggi dapat mestimulasi hati untuk mensekresi Insulin-like Growth factor-I (IGF-I) yang dapat memberikan efek hipoglikemia (Bunting, et al., 2006) 


\section{Pengaruh Rebusan sereh terhadap respon stress oksidatif}

Untuk mengetahui pengaruh pemberian rebusan sereh terhadap peroksidasi lipid dan kemampuan untuk meningkatkan kapasitas antioksidan, dilakukan dengan mengukur konsentrasi Malondialdehid (MDA) dan Total Antioxidant capacity (TAC). Hasil pengukuran konsentrasi MDA pada kelompok diabetes menunjukan bahwa terdapat peningkatan kadar MDA pada serum dan hepar bila dibandingkan dengan kelompok normal. Pengukuran kadar MDA pada kelompok K4 dan K5 menunjukan bahwa terdapat penurunan konsentrasi MDA pada serum dan hepar secara signifikan dengan $\mathrm{p}=0.00$, sedangkan pemberian rebusan sereh pada kelompok normal tidak menunjukan adanya perbedaan yang signifikan bila dibandingkan dengan kelompok normal (Tabel 3.)

Tabel 3. Pengaruh rebusan sereh terhadap konsentrasi MDA pada serum dan hepar

\begin{tabular}{lcc}
\hline \multirow{2}{*}{ Kelompok perlakuan } & \multicolumn{2}{c}{ Konsentrasi MDA } \\
\cline { 2 - 3 } & Serum $(\mathrm{nmol} / \mathrm{ml})$ & Hepar $(\mathrm{nmol} / \mathrm{gr})$ \\
\hline K1 : Normal & 2.12 & 3.21 \\
K2 : Normal + rebusan sereh & $1.61^{\mathrm{a}}$ & $2.84^{\mathrm{a}}$ \\
K3 : Diabetes & $9.09^{\mathrm{b}}$ & $9.77^{\mathrm{b}}$ \\
K4 : Diabetes + glibenklamid & $2.60^{\mathrm{a}}$ & $3.63^{\mathrm{a}}$ \\
K5 : Diabetes +rebusan sereh & $3.87^{\mathrm{b}}$ & $4.42^{\mathrm{b}}$ \\
\hline
\end{tabular}

Keterangan $:^{a}$ ) menunjukan $\mathrm{p}>0.05$, dan ${ }^{\mathrm{b}}$ ) menunjukan $\mathrm{P}<0.05$ dibandingkan dengan kelompok $\mathrm{K} 1$

Hasil penelitian menunjukan bahwa pada tikus diabetes yang diinduksi STZ terjadi peningkatan konsentrasi MDA. Tingginya kadar glukosa pada tikus diabetes dapat memicu terbentuknya radikal bebas yang disebabkan oleh peroksidasi lipid sehingga kadar MDA meningkat (Arora, et al., 2013). Hiperglikemi pada diabetes dapat menyebabkan stress oksidatif melalui beberapa mekanisme, antara lain terjadinya autooksidasi glukosa pada gugus aldehid sehingga membentuk superoksida $\left(\mathrm{O}_{2}\right)$, radikal hidroksil $\left(\mathrm{OH}^{*}\right)$ dan hydrogen peroksida $\left(\mathrm{H}_{2} \mathrm{O}_{2}\right)$ (Dierckx et al., 2003). Tingginya kadar glukosa juga akan meningkatkan proses glikosilasi non enzimatik pada protein yang disebabkan oleh oksidasi gugus aldehid pada glukosa. Proses ini menyebabkan terbentuknya advanced glycation end products (AGEs) dan radikal bebas yang dapat meningkatkan stress oksidatif (Giacco \& Brownlee, 2010). Pengikatan AGEs pada reseptor makrofag (RAGE) dapat menyebabkan sintesis sitokin dan growth factor serta peningkatan stress oksidatif (Subandrate, 2016)

Kadar MDA serum dan hepar pada kelompok diabetes yang diberi perlakuan rebusan lebih rendah bila dibandingkan dengan kelompok diabetes. Hal ini menunjukan bahwa rebusan sereh mampu menekan peroksidasi lipid yang disebabkan oleh toksisitas STZ. Arhoghro \& Kpomah, (2014) juga menemukan bahwa ekstrak air daun sereh dengan konsentrasi 5\% dan 10\% dapat menurunkan kadar MDA pada tikus putih yang diinduksi dengan cisplatin. Campos et al., (2014) juga telah mengemukan aktivitas tanaman sereh dalam memperbaiki kerusakan oksidatif. Ekstrak methanol tanaman sereh dengan konsentrasi $10 \mu \mathrm{g}$ dan $100 \mu \mathrm{g}$ dapat menghambat sintesis ROS pada sel HUVEC yang diinduksi dengan peroksida. 
Hasil pengukuran TAS menunjukan bahwa pada kelompok diabetes terdapat penurunan TAS secara signifikan bila dibandingkan dengan kelompok normal. Perlakuan dengan glibenklamid dan rebusan sereh berpengaruh terhadap kenaikan TAS baik dalam serum maupun hepar. Peningkatan kadar TAS dalam terlihat lebih tinggi bila dibandingkan dengan serum. Pemberian rebusan sereh pada normal juga mampu meningkatkan TAS dalam hepar (Tabel 4.).

Tabel 4. Pengaruh pemberian rebusan sereh terhadap total antioxidant Capacity pada serum dan hepar

\section{Kelompok perlakuan}

$\mathrm{K} 1$ : Normal

K2 : Normal + rebusan sereh

K3 : Diabetes

K4 : Diabetes + glibenklamid

K5 : Diabetes +rebusan sereh

Keterangan : ${ }^{a}$ ) menunjukan $\mathrm{p}>0.05$, dan ${ }^{\mathrm{b}}$ ) menunjukan $\mathrm{P}<0.05$ dibandingkan dengan kelompok K1

\section{Total Antioxidant Status (TAS)}

\begin{tabular}{cc}
\hline Serum $(\mathrm{mmol} / \mathrm{ml})$ & Hepar $(\mathrm{mmol} / \mathrm{gr})$ \\
\hline 2.13 & 2.62 \\
$2.53^{\mathrm{a}}$ & $4.34^{\mathrm{b}}$ \\
$0.44^{\mathrm{b}}$ & $0.44^{\mathrm{b}}$ \\
$1.94^{\mathrm{a}}$ & $3.58^{\mathrm{b}}$ \\
$1.42^{\mathrm{a}}$ & $2.38^{\mathrm{a}}$
\end{tabular}

Total antioxidant status (TAS) adalah parameter yang digunakan untuk mengukur total antioksidan di dalam tubuh (Wu et al., 2017). Hasil penelitian menunjukan terjadinya penurunan TAS pada tikus wistar diabetes. Penurunan antioksidan terjadi sebagai respon adanya stress oksidatif. Jika TAS tinggi maka sel akan dapat menekan adanya stress oksidatif sehingga kadar MDA menjadi normal. TAS merupakan jumlah seluruh antioksidan baik endogenus dan eksogenus (Rani \& Mythili, 2014). Opara et al., (1999) menunjukan bahwa pada penderita diabetes tipe 2 terjadi penurunan total antioksidan status.

Hasil penelitian menunjukan bahwa pada kelompok diabetes yang diberi rebusan sereh dapat meningkatkan TAS dibandingkan dengan kelompok non diabetes. Hal tersebut terjadi karena senyawa bioaktif yang terdapat dalam tanaman sereh mampu berperan sebagai antioksidan. Kandungan utama tanaman sereh $C$-glycosilflavone orientin, isoorientin dan chlorogenic acid. Golongan senyawa tersebut telah dilaporkan memiliki efek hipoglikemik pada tikus yang diinduksi STZ, serta memiliki kemampuan sebagai scavenging radikal bebas (Cheel, et al., 2005). Sedangkan Somparn, et al., (2018) melaporkan bahwa ekstrak air tanaman sereh mengandung senyawa polifenol utama yaitu, rutin, isoquercetin, cathecin dan quercetin. Ekstrak air tanaman tersebut juga dilaporkan dapat menurunkan indek aterogenik, kadar kolesterol dan LDL, melalui mekanime akspresi SREP1c dan HMGR. Menurut Coskun, et al., (2005) quercetin dapat berperan dalam menurunkan stress oksidatif dan mempertahankan integritas sel $\beta$-pankkreas pada tikus putih diabetes yang diinduksi STZ. Babu, et al., (2006) juga menunjukan bahwa senyawa polifenol seperti catechin dapat menurunkan tingkat stress oksidatif pada tikus putih diabetes. Hasil penelitian ini menunjukan bahwa rebusan sereh memiliki potensi sebagai agen terapi diabetes untuk mencegah terjadinya komlikasi lebih lanjut, namun masih diperlukan penelitian lebih lanjut untuk mengetahui mekanismenya dalam menurunkan peroksidasi lipid.

\section{SIMPULAN}


Pemberian rebusan sereh dengan konsentrasi $3.6 \mathrm{ml} / 200 \mathrm{mg}$ BB yang diberikan selama 14, berpengaruh terhadap penurunan konsentrasi malondialdehid (MDA) dan dapat meningkatkan total antioksidan status (TAS) pada tikus wistar jantan diabetes yang diinduksi dengan STZ pada dosis tunggal sebesar $60 \mathrm{mg} / \mathrm{kg} \mathrm{BB}$.

\section{UCAPAN TERIMA KASIH}

Kami ucapkan terima kasih kepada Kementerian Riset Teknologi dan Pendidikan Tinggi Republik Indonesia serta UPPM AAK Manggala Yogyakarta, atas dukungan dana penelitian tahun 2017

\section{DAFTAR PUSTAKA}

Adeneye, A. A., \& Agbaje, E. O. (2007). Hypoglycemic and hypolipidemic effects of fresh leaf aqueous extract of Cymbopogon citratus Stapf. in rats. Journal of Ethnopharmacology. https://doi.org/10.1016/j.jep.2007.03.034

Akbarzadeh, A., Norouzian, D., Mehrabi, M. R., Jamshidi, S., Farhangi, A., Allah Verdi, A., ... Lame $\mathrm{Rad}$, B. (2007). Induction of Diabetes by Streptozotocin in rats. Indian Journal of Clinical Biochemistry, 22(2), 60-64. https://doi.org/10.1007/BF02913315

Arhoghro, E. . ., \& Kpomah, E. . (2014). Original Research Article Cymbopogon Citratus Aqueous Extract Alleviates Cisplatin-Induced Hepatic Oxidative Stress and Toxicity in Albino Rats. Int. J. Curr. Microbiol. App. Sci, 3(4), 586-604.

Arora, R., Pal Vig, A., \& Arora, S. (2013). Lipid Peroxidation: A Possible Marker for Diabetes. Journal of Diabetes \& Metabolism, S11(007). https://doi.org/10.4172/2155-6156.s11-007

Babu, P. V. A., Sabitha, K. E., \& Shyamaladevi, C. S. (2006). Therapeutic effect of green tea extract on oxidative stress in aorta and heart of streptozotocin diabetic rats. Chemico-Biological Interactions, 162(2), 114-120. https://doi.org/10.1016/j.cbi.2006.04.009

Bunting, K., Wang, J., \& Shannon, F. M. (2006). Control of Interleukin-2 Gene Transcription: A Paradigm for Inducible, Tissue-Specific Gene Expression. Vitamin \& Hormon, 74, 105-154. https://doi.org/https://doi.org/10.1016/S0083-6729(06)74005-5

Campos, J., Schmeda-Hirschmann, G., Leiva, E., Guzmán, L., Orrego, R., Fernández, P., ... Aguayo, C. (2014). Lemon grass (Cymbopogon citratus (D.C) Stapf) Polyphenols Protect Human Umbilical Vein Endothelial Cell (HUVECs) from Oxidative Damage Induced by High Glucose,Hydrogen Peroxide and Oxidised Low-density Lipoprotein. Food Chemistry, 151, 175-181. https://doi.org/10.1016/j.foodchem.2013.11.018

Cheel, J., Theoduloz, C., Rodríguez, J., \& Schmeda-Hirschmann, G. (2005). Free Radical Scavengers and Antioxidants from Lemongrass (Cymbopogon citratus (DC.) Stapf.). Journal of Agricultural and Food Chemistry, 53(7), 2511-2517. https://doi.org/10.1021/jf0479766

Cho, N. H., Shaw, J. E., Karuranga, S., Huang, Y., da Rocha Fernandes, J. D., Ohlrogge, A. W., \& Malanda, B. (2018). IDF Diabetes Atlas: Global Estimates of Diabetes Prevalence for 2017 and Projections for 2045. Diabetes Research and Clinical Practice, 138, 271-281. https://doi.org/10.1016/j.diabres.2018.02.023

Coskun, O., Kanter, M., Korkmaz, A., \& Oter, S. (2005). Quercetin, a Flavonoid Antioxidant, Prevents and Protects Streptozotocin-induced Oxidative Stress and $\beta$-cell Damage in Rat Pancreas. Pharmacological Research, 51(2), 117-123. https://doi.org/10.1016/j.phrs.2004.06.002

Dierckx, N., Horvath, G., van Gils, C., Vertommen, J., van de Vliet, J., De Leeuw, I., \& Manuel-yKeenoy, B. (2003). Oxidative Stress Status in Patients with Diabetes Mellitus: Relationship to diet. European Journal of Clinical Nutrition, 57(8), 999-1008. https://doi.org/10.1038/sj.ejcn.1601635

Ekpenyong, C. E., Akpan, E. E., \& Daniel, N. E. (2014). Phytochemical Constituents , Therapeutic Applications and Toxicological Profile of Cymbopogon citratus Stapf ( DC ) Leaf Extract . Journal of Pharmacognosy and Phytochemistry, 3(1), 133-141.

Erlidawati, E., Safrida, S., \& Mukhlis, M. (2018). Potensi Antioksidan Sebagai Antidiabetes. Potensi Antioksidan Sebagai Antidiabetes, 1-11. https://doi.org/10.52574/syiahkualauniversitypress.350 
Garba, H. A., Mohammed, A., Ibrahim, M. A., \& Shuaibu, M. N. (2020). Effect of Lemongrass (Cymbopogon citratus Stapf) Tea in a Type 2 Diabetes Rat Model. Clinical Phytoscience, 6(1). https://doi.org/10.1186/s40816-020-00167-y

Giacco, F., \& Brownlee, M. (2010). Oxidative Stress and Diabetic Complications. Circ Res, 107(9), 1058-1070. https://doi.org/10.1161/CIRCRESAHA.110.223545.Oxidative

Haidari, F., Omidian, K., Rafiei, H., Zarei, M., \& Shahi, M. M. (2013). Green Tea (Camellia sinensis) Supplementation to Diabetic Rat Improves Serum and Hepatic Oxidative Stress Markers. Irranian Journal of Pharmaceutical Research, 12(1), 109-114.

Kusmardiyani, S., Alfianti, F., \& Fidrianny, I. (2016). Antioxidant Profile and Phytochemical Content of Three Kinds of Lemongrass Grown in West Java-Indonesia. Asian Journal of Pharmaceutical and Clinical Research, 9(4).

Martina, J. S., Ramar, L. A. P., Silaban, M. R. I., Luthfi, M., \& Govindan, P. A. P. (2019). Antiplatelet Effectivity between Aspirin with Honey on Cardiovascular Disease Based on Bleeding Time Taken on Mice. Journal of Medical Sciences, 7(20), 3416-3420. https://doi.org/10.3889/oamjms.2019.431

Mirghani, M. E. S., Liyana, Y., \& Parveen, J. (2012). Bioactivity analysis of lemongrass (Cymbopogan citratus) essential oil. International Food Research Journal, 19(2), 569-575.

Nugroho, A. E. (2006). Animal Models of Diabetes Mellitus: Pathology and Mechanism of Some Diabetogenics. Biodiversitas, Journal of Biological Diversity, 7(4), 378-382. https://doi.org/10.13057/biodiv/d070415

Opara, E. C., Abdel-Rahman, E., Soliman, S., Kamel, W. A., Souka, S., Lowe, J. E., \& Abdel-Aleem, S. (1999). Depletion of Total Antioxidant Capacity in Type 2 Diabetes. Metabolism: Clinical and Experimental, 48(11), 1414-1417. https://doi.org/10.1016/S0026-0495(99)90152-X

Pieme, C. A., Tatangmo, J. A., Simo, G., Biapa Nya, P. C., Ama Moor, V. J., Moukette Moukette, B., ... Sobngwi, E. (2017). Relationship Between Hyperglycemia, Antioxidant Capacity and Some Enzymatic and Non-enzymatic Antioxidants in African Patients with Type 2 Diabetes. BM

Rani, J. A., \& Mythili, S. V. (2014). Study on Total Antioxidant Status in Relation to Oxidative Stress in Type 2 Diabetes Mellitus. Journal of Clinical and Diagnostic Research, 8(3), 108-110. https://doi.org/10.7860/JCDR/2014/7603.4121

Setiawan, B., \& Suhartono, E. (2005). Stres Oksidatif dan Peran Antioksidan pada Diabetes Melitus. Majalah Kedokteran Indonesia, 55, 86-91.

Somparn, N., Saenthaweeuk, S., Naowaboot, J., Thaeomor, A., \& Kukongviriyapan, V. (2018). Effect of Lemongrass Water Extract Supplementation on Atherogenic Index and Antioxidant Status in Rats. Acta Pharmaceutica, 68(2), 185-197. https://doi.org/10.2478/acph-2018-0015

Subandrate. (2016). Hubungan Kadar Glukosa Darah dengan Peroksidasi Lipid pada Pasien Diabetes Melitus tipe 2. CDK, 43(7), 487-489.

Szkudelski, T. (2001). The Mechanism of Alloxan and Streptozotocin Action in B Cells ofTthe Rat Pancreas. Physiological Research, 50(6), 537-546.

Tarigan, T. J. E., Yunir, E., Subekti, I., Pramono, L. A., \& Martina, D. (2015). Profile and analysis of diabetes chronic complications in outpatient diabetes clinic of Cipto Mangunkusumo Hospital, Jakarta. Medical Journal of Indonesia, 24(3), 156-162. https://doi.org/10.13181/mji.v24i3.1249

Waltner-Law, M. E., Wang, X. L., Law, B. K., Hall, R. K., Nawano, M., \& Granner, D. K. (2002). Epigallocatechin gallate, a constituent of green tea, represses hepatic glucose production. Journal of Biological Chemistry, 277(38), 34933-34940. https://doi.org/10.1074/jbc.M204672200

Widaryanti, B., \& Tripramatasari, F. L. (2021). Efek Rebusan Sereh ( Cymbopogon citratus ) Terhadap Kadar Glukosa dan Profil Lipid Tikus Wistar Diabetes. Biowallacea, 8(1), 1-9.

Wu, R., Feng, J., Yang, Y., Dai, C., Lu, A., Li, J., ... Du, X. B. (2017). Significance of Serum Total Oxidant/Antioxidant Status in Patients with Colorectal Cancer. PLoS ONE, 12(1), 1-13. https://doi.org/10.1371/journal.pone.0170003

Zatalia, S. R., \& Sanusi, H. (2013). The role of antioxidants in the pathophysiology, complications, and management of diabetes mellitus. Acta Medica Indonesiana, 45(2), 141-147. 